\title{
Novel oligosaccharide has suppressive activity against human leukemia cell proliferation
}

\author{
O. Hosomi $\cdot$ Y. Misawa $\cdot$ A. Takeya $\cdot$ Y. Matahira $\cdot$ \\ K. Sugahara $\cdot$ Y. Kubohara $\cdot$ F. Yamakura $\cdot$ S. Kudo
}

Received: 11 January 2008 /Revised: 12 June 2008 / Accepted: 28 July 2008 / Published online: 26 August 2008

(C) The Author(s) 2008. This article is published with open access at Springerlink.com

\begin{abstract}
Various oligosaccharides containing galactose(s) and one glucosamine (or $\mathrm{N}$-acetylglucosamine) residues with $\beta 1-4, \alpha 1-6$ and $\beta 1-6$ glycosidic bond were synthesized; Gal $\beta 1-4 \mathrm{GlcNH}_{2}$, Gal $\alpha 1-6 \mathrm{GlcNH}_{2}, \mathrm{Gal} \alpha 1-$ 6GlcNAc, Gal $\beta 1-6 \mathrm{GlcNH}_{2}, \mathrm{Gal} \beta 1-4 \mathrm{Gal} \beta 1-4 \mathrm{GlcNH}_{2}$ and Gal $\beta 1-4 \mathrm{Gal} \beta 1-4 \mathrm{GlcNAc}$. Gal $\alpha 1-6 \mathrm{GlcNH}_{2}\left(\mathrm{MelNH}_{2}\right)$ and glucosamine $\left(\mathrm{GlNNH}_{2}\right)$ had a suppressive effect on the proliferation of K562 cells, but none of the other saccharides tested containing GlcNAc showed this effect. On the other hand, the proliferation of the human normal umbilical cord fibroblast was suppressed by none of the saccharides other than $\mathrm{GlcNH}_{2}$. Adding Gal $\alpha 1-6 \mathrm{GlcNH}_{2}$ or glucosamine to the culture of K562 cell, the cell number decreased strikingly after $72 \mathrm{~h}$. Staining the remaining cells with Cellstain Hoechst 33258, chromatin aggregation was found in many cells, indicating the occurrence of cell death. Furthermore, all
\end{abstract}

O. Hosomi $(\square)$

Department of Health Science,

School of Sports and Health Science, Juntendo University,

1-1, Hiragagakuendai, Inba-gun,

Inba-mura, Chiba 270-1695, Japan

e-mail: hosomi@sakura.juntendo.ac.jp

Y. Misawa $\cdot$ Y. Matahira

Yaizu Suisankagaku Industry Co., Ltd.,

5-8-13 Kogawashinmachi,

Yaizu-city, Shizuoka 425-8570, Japan

\section{A. Takeya}

Department of Legal Medicine, School of Medicine,

St. Marianna Medical University,

Kawasaki-City 261-8511, Japan

K. Sugahara

Faculty of Agriculture, Utsunomiya University,

Utsunomiya City, Tochigi 321-8505, Japan of the cells were stained with Gal $\alpha 1-6$ GlcNH-FITC (MelNH-FITC). Neither the control cells nor the cells incubated with glucosamine were stained. On the other hand, when GlcNH-FITC was also added to cell cultures, some of them incubated with $\mathrm{Gal} \alpha 1-6 \mathrm{GlcNH}_{2}$ were stained. The difference in the stainability of the K562 cells by Gal $\alpha 1-$ 6GlcNH-FITC and GlcNH-FITC suggests that the intake of Gal $\alpha 1-6 \mathrm{GlcNH}_{2}$ and the cell death induced by this saccharide is not same as those of glucosamine. The isolation of the Gal $\alpha 1-6 \mathrm{GlcNH}_{2}$ binding protein was performed by affinity chromatography (melibiose-agarose) and LC-MS/MS, and we identified the human heterogeneous ribonucleoprotein (hnRNP) A1 $(34.3 \mathrm{kDa})$ isoform protein $(30.8 \mathrm{kDa})$. The hnRNP A1 protein was also detected from the eluate(s) of the MelNH-agarose column by the immunological method (antihnRNP-A1 and HRP-labeled anti-mouse $\operatorname{IgG}(\gamma)$ antibodies).
Y. Kubohara

Biosignal Research Center,

Institute for Molecular Regulation,

Gunma University,

Showa-machi,

Maebashi-city, Gunma 371-8511, Japan

F. Yamakura

Department of Chemistry,

Juntendo University School of Medicine,

1-1 Hiragagakuendai,

Inba, Chiba 270-1606, Japan

S. Kudo

Department of Anatomy,

Gunma University School of Medicine,

Maebashi City, Gunma 371-8511, Japan 
Keywords Glucosamine - Human leukemia cell · Heterogeneous nuclear ribonucleoprotein A1 . Oligosaccharide

$\begin{array}{ll}\begin{array}{l}\text { Abbreviations } \\ \text { GlcNAc }\end{array} & N \text {-acetylglucosamine } \\ \text { GlcNH } & \text { glucosamine } \\ \text { Mel } & \text { melibiose } \\ \text { MelNAc } & \text { Gal } \alpha 1-6 G l c N A c \\ \text { MelNH }_{2} & \text { Gal } \alpha 1-6 \text { GlcNH } \\ \text { LacNAc }^{2} \\ \text { LacNH }_{2} & N \text {-acetyllactosamine } \\ \text { alloLacNAc } & \text { lactosamine } \\ \text { alloLacNH } & N \text {-acetyl-allolactosamine } \\ \text { GalLacNAc } & \text { allolactosamine } \\ \text { GalLacNH } & \text { galactosyl- } N \text {-acetyllactosamine } \\ \text { heterogeneous nuclear } & \text { hnRNP A1 } \\ \text { ribonucleoprotein A1 } & \end{array}$

\section{Introduction}

It has been reported that glucosamine $\left(\mathrm{GlcNH}_{2}\right)$ is an amino monosaccharide occurring in connective and cartilage tissues of humans and other animals [1-3]. It is well known that this amino sugar is a precursor substance of glycosaminoglycans [4], and that it has an effect on nitric oxide synthesis [5] and a reparation effect on arthrodial cartilage such as in case of osteoarthritis [6-8]. Furthermore, it has been suggested that glucosamine benefited some patients with knee osteoarthritis and that it aided wound healing [9, 10]. Quastel and Cantero observed that $\mathrm{GlcNH}_{2}$ injection into mice with tumor sarcoma 37 inhibited the tumor growth, and suggested that administration of $\mathrm{GlcNH}_{2}$ might divert adenosine triphosphate (ATP) activity to affect the rates of the metabolic paths involved in tumor proliferation [11]. Molnar and Bekesi reported that addition of $\mathrm{GlcNH}_{2}$ or mannosamine $\left(\mathrm{ManNH}_{2}\right)$ in Ehrlich ascites carcinoma and Sarcoma 180 ascites tumor cells in vitro provoked striking cytoplasmic and nuclear changes, including vacuolization of the cytoplasm and various degrees of disintegration [12]. Moreover, they found that continuous vein infusion with glucosamine resulted in a high rate of tumor regression in rats with i.m. Walker 256 carcinosarcoma [13]. Ichikawa et al. reported that incubation of mastocytoma P-815 cells with $5 \mathrm{mM}$ glucosamine resulted in a marked inhibition of growth and significant reduction of cellular uptake and oxidation of glucose and cellular level ATP, and that glucosamine also reduced the uridine nucleotides and accumulated UDP-GlcNAc [14].

It has also been reported that a melibiose-binding protein composed of $-58,32,26 \mathrm{kDa}$ polypeptides was isolated from human spleen, and the protein was mainly anti- $\alpha \mathrm{Gal}$ antibody and it preferred Gal $\alpha 1-6$ to Gal $\alpha 1-3$ [15]. Galectin-1 (14 kDa), which is a generously $\beta$-galactose binding protein, was isolated from bovine heart (BHL-14) and reexamined regarding the binding specificity against saccharides, and it was observed that terminal $\alpha$-linked galactose, rather than $\beta$-galactose in $N$-acetyllactosamine was the ligand for the galectin-1 [16]. Moreover, it is supposed that galectin-1 ( $\beta$-galactose binding protein), which was expressed by stromal cells in human thymus and lymph nodes, induced apoptosis of activated human Tcells and human T-leukemia cell lines, and that galectin-1, which induced apoptosis, required expression of CD45 [17]. McReynolds et al. showed that human immunodeficiency virus (HIV-1) recombinant gp 120 (rgp 120) recognized non-natural glycosphingolipids, cellobiosyl and melibiosyl ceramides but not those lacking a lipid component [18].

We have taken notice of the various functions of glucosamine, such as its anti-inflammatory and other properties in humans and other animals, and have been furthering the development of novel functional oligosaccharides. Thus, we synthesized several oligosaccharides having a glucosamine residue at the reducing terminal, using several $\alpha$ - and $\beta$-galactosidases. Moreover, we examined their effects on some human cancer and normal cells, and we attempted to identify Gal $\alpha 1-6 \mathrm{GlcNH}_{2}$ binding protein from K562 cells.

\section{Materials and methods}

\section{Saccharides}

Lactosamine $\left(\mathrm{LacNH}_{2}, \mathrm{Gal} \beta 1-4 \mathrm{GlcNH}_{2}\right)$, allolactosamine $\left(\right.$ AlloLacNH 2, Gal $\left.\beta 1-6 \mathrm{GlcNH}_{2}\right)$, MelNAc (Gal $\alpha 1-$ 6GlcNAc), $\mathrm{MelNH}_{2}\left(\mathrm{Gal} \alpha 1-6 \mathrm{GlcNH}_{2}\right)$, galactosyl- $N$ acetyllactosamine (GalLacNAc, Gal $\beta 1-4 \mathrm{Gal} \beta 1-4 \mathrm{GlcNAc}$ ) and galactosyllactosamine $\left(\mathrm{GalLacNH} \mathrm{H}_{2}, \mathrm{Gal} \beta 1-4 \mathrm{Gal} \beta 1-\right.$ $4 \mathrm{GlcNH}_{2}$ ) were synthesized by reverse reactions of $\alpha$ - and $\beta$-galactosidases of bacteria, Aspergillus niger and Aspergillus oryzae, respectively (PT No. 2004-352672 and 2004-352673). N-acetyllactosamine (LacNAc, Gal $\beta 1-$ 4GlcNAc), $N$-acetyl-allolactosamine (AlloLacNAc, Gal $\beta 1-$ $6 \mathrm{GlcNH}_{2}$ ) and chito oligosaccharides (bi-, tri-, tetra- and penta-: $\mathrm{GlcNH}_{2}\left[\beta 1-4 \mathrm{GlcNH}_{2}\right]_{1 \sim 4}$ ) were supplied by Yaizu Suisankagaku Ind. Co. (Yaizu, Japan). Each oligosaccharide was dissolved in the $0.05 \mathrm{M}$ 4-(2-hydroxyethyl)1-piperazineethanesulfonic acid (HEPES), pH 7.0, buffer containing $0.15 \mathrm{M} \mathrm{NaCl}$, and filtrated (pore size $0.45 \mu \mathrm{m}$, Advantec Co., Tokyo) to sterilize. Fluorescein isothiocyanate-labeled Gal $\alpha 1-6 \mathrm{GlcNH}_{2}$ and $\mathrm{GlcNH}_{2}$ (MelNH-FITC and GlcNH-FITC) were synthesized by us. Briefly, reaction mixtures contained equal moles of each 
saccharide and FITC in $0.025 \mathrm{M}$ phosphate buffer, $\mathrm{pH}$ 9.0, and were incubated for $30 \mathrm{~min}$ at room temperature and purified by thin layer chromatography (TLC) using chloroform/methanol (70/30) developmental solution. After TLC development, the synthesized MelNH- and GlcNH-FITC were isolated and recovered. Cellstain Hoechst 33258 (H33258) was purchased from Sigma-Aldrich Co. (St. Louis, MO, USA). Antibodies, mouse monoclonal antihnRNP-A1 antibody and horse radish peroxidase (HRP)labeled goat anti-mouse $\operatorname{IgG}(\gamma)$, and polyvinylidene fluoride (PVDF) membrane for immunological detection were purchased from KPL (Kirkegaard and Perry Laboratories, Gaithersburg, MD, USA), Sigma and Millipore (Bedford, MA, USA), respectively. Other chemicals of analytical grade were obtained from Wako Pure Chemical Industries, Ltd. (Osaka, Japan) and Sigma.

\section{Cell culture}

Cells (human leukemia cell, K562 cells; human normal umbilical cord fibroblast (HUC-F2) cells) were purchased from the Riken Cell Bank (Tsukuba, Japan). Cell culture was carried out in Ham F-12 medium [Sigma; containing $10 \%$ fetal bovine serum (FBS)] for K562 cells and in $\alpha$ MEM (alpha minimum essential medium, containing 10\% FBS, Sigma) for HUC-F2 cells in a $5 \% \mathrm{CO}_{2}$ humidified air environment for $3-4$ days at $37^{\circ} \mathrm{C}$ using Petri dishes $(\phi 70 \times$ $15 \mathrm{~mm})$. Cells were collected by centrifugation at $1,000 \mathrm{rpm}$ for $10 \mathrm{~min}$, carefully aspirated and resuspended with fresh medium. In the case of HUC-F2 cell culture, confluent cells were treated with $0.25 \%$ trypsin- $0.2 \%$ ethylenediaminetetraacetic acid (EDTA) in medium (Invitrogen, Co., Carlsbad, CA. USA), carefully shaken for 5$10 \mathrm{~min}$ at $37^{\circ} \mathrm{C}$, centrifuged at $1,000 \mathrm{rpm}$ for $10 \mathrm{~min}$ and washed with $\alpha$ MEM medium (10\% FBS). Cells were suspended again in fresh medium and the number of cells was adjusted to $1.0 \sim 1.7 \times 10^{5} \mathrm{cells} / \mathrm{ml}$.

Suppression experiment of cell proliferation by saccharides

The suppression experiments of the cell proliferation were carried out using cells (K562 and HUC-F2) and saccharides as inhibitors in triplet. The cell culture medium $(0.36 \mathrm{ml})$ of K562 was added to a 24-well plate, and incubated with 5 $10 \mathrm{mM}$ saccharides using 50 and $100 \mathrm{mM}$ as their stock solutions for $24 \sim 72 \mathrm{~h}$ in the $\mathrm{CO}_{2}$ incubator. As a blank control, an aliquot of $50 \mathrm{mM}$ HEPES buffered saline ( $\mathrm{pH}$ 7.0), in place of saccharide, was added to the cell culture. After incubation, the cell number was counted using a cell counting chamber, except for the injured and shrunk cells, under the microscope at $\times 100 \sim 200$ magnifications, without cell staining by dye. After incubation of HUC-F2 with or without saccharides, the cell culture was aspirated carefully and $0.2 \mathrm{ml}$ of $0.25 \%$ trypsin- $0.2 \%$ EDTA was added to each well. Careful shaking was performed as described above, and fresh medium $(0.2 \mathrm{ml})$ was added and the cell number was counted in the same manner as described above.

Cell staining with Cellstain Hoechst 33258, MelNH-FITC and GlcNH-FITC

In order to determine cell death, we observed nuclear chromatin aggregates of cultured cells with or without saccharides $\left(\mathrm{GlcNH}_{2}\right.$ or $\left.\mathrm{MelNH}_{2}\right)$ using Cellstain Hoechst 33258 fluorescence dye, H33258, (2 $\mathrm{mM}$ solution in $50 \mathrm{mM}$ Tris-HCl, $\mathrm{pH} 7.4$, buffered saline). After staining cells $(15 \mu \mathrm{l}$ of suspension) with dye $(1 \mu \mathrm{l})$ about $5 \mathrm{~min}$ at room temperature, aliquots $(5 \sim 10 \mu \mathrm{l})$ of cell suspension were dropped on slide glass and covered with cover glass without washing with fresh medium. MelNH-FITC and GlcNH-FITC fluorescent dyes $(2 \mathrm{mM}$ solution in $50 \mathrm{mM}$ Tris-HCl, pH 7.4, buffered saline) were used for investigation of stainability of the cells which were cultured with oligosaccharide, using the same procedure as described above. The fluorescent cells were observed by fluorescent microscope at $346 \mathrm{~nm}$ for $\mathrm{H} 33258$ and $492 \mathrm{~nm}$ for MelNHand GlcNH-FITC, respectively. Each cell sample dyed with H33258 was also observed optically.

\section{Extraction of melibiose binding protein}

K562 cells (about $5 \times 10^{9}$ ) cultured without any saccharide were collected by centrifugation at $1,000 \mathrm{rpm}$ for $10 \mathrm{~min}$ at room temperature, washed thoroughly with $10 \mathrm{mM}$ Tris$\mathrm{HCl}$ buffer, $\mathrm{pH} 7.4$, containing $0.15 \mathrm{M} \mathrm{NaCl}$ and exposed to $2 \mathrm{ml}$ of $0.1 \%$ Triton X-100 and $100 \mathrm{mM}$ melibiose in the same buffer. After gentle shaking by magnetic stirrer, the cell lysate was sonicated at $1.5 \mathrm{~kW}$ for $2 \mathrm{~min}$ at $4^{\circ} \mathrm{C}$ and centrifuged at $12,000 \mathrm{rpm}$ for $30 \mathrm{~min}$ at $4^{\circ} \mathrm{C}$. The supernatant was collected and the precipitate was washed with the same buffer. The supernatants were mixed and dialyzed two times against $500 \mathrm{ml}$ of the same Tris- $\mathrm{HCl}$ buffer without melibiose.

\section{Affinity chromatography}

The dialyzed sample was applied to affinity column chromatography at $4^{\circ} \mathrm{C}$, and the melibiose-binding material(s) was isolated, using a modification of the method of Sharma et al. [15]. Briefly, the cell extract was applied to the immobilized melibiose (Seikagaku Co. Tokyo) column, $1.0 \times 5 \mathrm{~cm}$, equilibrated with $10 \mathrm{mM}$ Tris- $\mathrm{HCl}$ buffer, pH 7.4, containing $0.1 \%$ Triton $\mathrm{X}-100,1 \mathrm{mM} \mathrm{CaCl}_{2}$ and $1 \mathrm{mM} \mathrm{MgCl}_{2}$, and the column was washed with about $100 \mathrm{ml}$ of the same buffer. The melibiose-binding material 
(s) was eluted with $0.4 \mathrm{M}$ melibiose in the same buffer, and each fraction $(1.4 \mathrm{ml})$ was collected. The elutant was used for the following experiments.

Furthermore, another affinity chromatography (MelNHagarose), in which the column was made by us using HiTrap $^{\text {TM }}$ NHS-activated HP column $(1$ mll; GE Healthcare, Uppsala, Sweden), was done as described above except for elution by $0.1 \mathrm{M} \mathrm{MelNH}_{2}$. Each sample, crude extract, unbound fraction and bound fraction (concentrated to about ten-fold), was tested for detection of the hnRNP A1 by immunological method.

Sodium dodecyl sulfate polyacrylamide gel electrophoresis

An aliquot $(15 \mu \mathrm{l})$ of each fraction eluted from the affinity (melibiose-) column was treated with the loading buffer (Invitrogen) without the SH-reagent, 2-mercaptoethanol (2 ME), for $3 \mathrm{~min}$ at $90^{\circ} \mathrm{C}$ and applied to sodium dodecyl sulfate polyacrylamide gel electrophoresis (SDS-PAGE; NuPAGE, $10 \%$ gel, Invitrogen) using NuPAGE MOPS buffer in accordance with the manufacturer's instructions. After electrophoresis, the slab gel was stained with silver staining (Daiichi Pure Chemicals Co. Ltd. Tokyo). The fractions, which contained melibiose binding material(s) were pooled and concentrated by Amicon Ultra-4 (Millipore, Co. Bedford, MA, USA) at 3,500 rpm for $40 \sim 60 \mathrm{~min}$ at $4^{\circ} \mathrm{C}$. A part $(15 \mu \mathrm{l})$ of the concentrated sample was loaded again on NuPAGE under reducing and non-reducing conditions for $3 \mathrm{~min}$ at $90^{\circ} \mathrm{C}$ and the gel was stained with silver staining.

LC-MS/MS analysis of the melibiose binding protein

In order to identify the $\mathrm{MelNH}_{2}$ binding protein, the sample $(30 \mu \mathrm{l})$ described above and acrylamide $(20 \mu \mathrm{mol})$ were mixed and treated for $3 \mathrm{~min}$ at $95^{\circ} \mathrm{C}$. The mixture was applied on a stacking gel and the cysteine residues were alkylated with acrylamide during SDS-PAGE [19]. After electrophoresis and silver staining, the corresponding band on the gel was cut out and digested with trypsin. The triptic peptides were subjected to LC-MS/MS analysis using API QSTAR Pulsar (I) hybrid mass spectrometer (Applied Biosystem, Foster City, CA, USA) with a nano-liquid chromatography (DiNa, KYA TECH Corporation, Tokyo, Japan). The nano-LC was carried out using Magic C18 column $(0.2 \mathrm{~mm} \mathrm{ID} \times 50 \mathrm{~mm})$ and peptides were eluted with $0.1 \%$ formic acid and $0.1 \%$ formic acid $90 \% \mathrm{CH}_{3} \mathrm{CN}$.

Protein on SDS-PAGE was identified with LC-MS/MS using Mascot search engine (Matrix Science, UK) and NCBI database.

Aliquot $(10 \mu \mathrm{l})$ of each sample (crude extract, unbound and bound fractions), which was obtained from MelNHagarose affinity chromatography was blotted on PVDF membrane. Membrane strips were treated or not treated with $0.3 \% \mathrm{H}_{2} \mathrm{O}_{2}$-methanol prior to immunostaining using mouse anti-hnRNP A1 monoclonal antibody and HRPlabeled goat anti-mouse $\operatorname{IgG}(\gamma)$ antibody.

\section{Results}

Suppressive effect of novel oligosaccharides on cancer cell proliferation

Among the oligosaccharides and monosaccharides tested, Gal $\alpha 1-6 \mathrm{GlcNH}_{2}\left(\mathrm{MelNH}_{2}\right)$ had the strongest suppressive effect on the proliferation of K562 cells (Fig. 1A). $\mathrm{GlcNH}_{2}$ was also an effective suppressor, and other oligosaccharides containing glucosamine $\left(\mathrm{LacNH}_{2}, \mathrm{AlloLacNH} \mathrm{H}_{2}\right.$ and $\mathrm{GalLacNH}_{2}$ ), but not $N$-acetylglucosamine (GlcNAc, LacNAc, AlloLacNAc and MelNAc), controlled on the proliferation of K562 cells slightly. Moreover, although

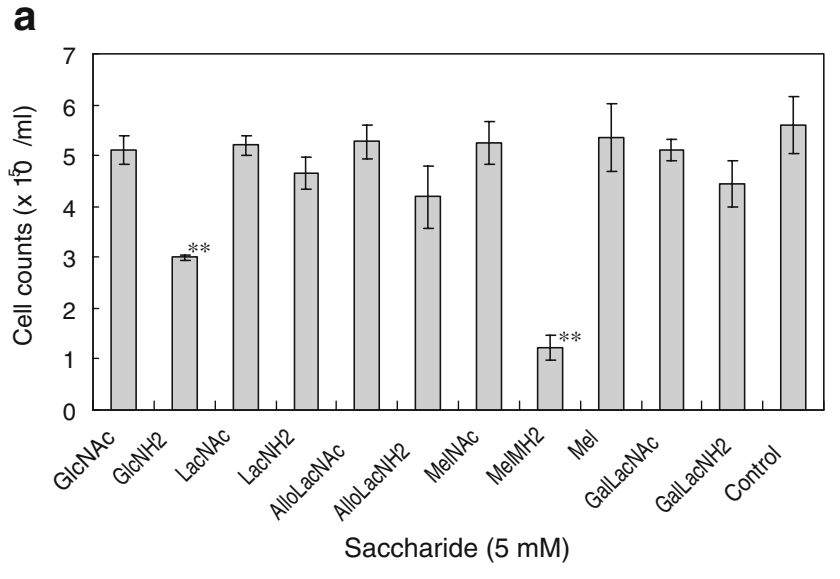

b

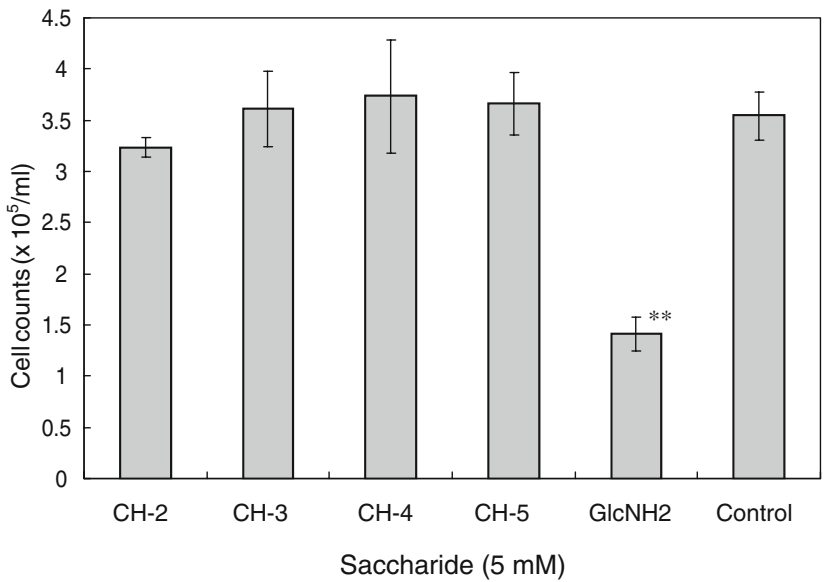

Fig. 1 Effects of various saccharides on human leukemia K562 cell proliferation (A) Each saccharide was added to the cell culture at $5 \mathrm{mM}$ concentration. (B) Chito-oligosaccharide (di, tri, tetra and penta: $\mathrm{CH}-2, \mathrm{CH}-3, \mathrm{CH}-4$ and $\mathrm{CH}-5,5 \mathrm{mM}$ concentration) effect on cell proliferation after $72 \mathrm{~h}$. Data are shown as the mean $\pm \mathrm{SD}$. $(n=3$ for all saccharide samples). ${ }^{* *} p<0.01$ compared with the control 
AlloLacNH $H_{2}$ and $\mathrm{MelNH}_{2}$ both have the 1-6 glycosidic bond between galactose and $\mathrm{GlcNH}_{2}$ residues, the former showed only a weak inhibitory effect on K562 cell proliferation. As shown in Fig. 1B, chito-oligosaccharides (chito-biose, chito-triose, chito-tetraose and chito-pentaose) were tested for their influence on the cell proliferation, and chito-biose $\left(\mathrm{GlcNH}_{2} \beta 1-4 \mathrm{GlcNH}_{2}\right)$ seemed to be slightly inhibitive against K562 cell proliferation. However, other chito oligosaccharides (chito-triose $\sim$ chito-pentaose) seemed to have no effect on the cell proliferation.

Neutral saccharides (such as glucose, galactose, lactose and melibiose) tested showed no influence on proliferation of K562 cells (part of the data not shown).

On the other hand, when human normal umbilical cord fibroblasts, HUC-F2 cells, were incubated with a series of oligosaccharides, the cell proliferation was influenced only by $\mathrm{GlcNH}_{2}$ (Fig. 2).

Mel and $\mathrm{MelNH}_{2}$ are structurally very similar, but their effects on the K562 cells are quite different. The question arises as to whether these saccharides share in part the same metabolic pathway, such as through an interaction with specific melibiose-binding protein(s). To clarify this, the effect of preincubation with Mel against anti-proliferation action of $\mathrm{MelNH}_{2}$ was examined using K562 cells (Fig. 3). Mel moderately inhibited $\mathrm{MelNH}_{2}$ action; after $72 \mathrm{~h}$ incubation the cell number increased about four-fold (compare left and middle columns in Fig. 3). However, simultaneous treatment of $\mathrm{Mel}$ and $\mathrm{MelNH}_{2}$ did not increase the cell number (data not shown), suggesting that they share the same binding molecule, at least in part.

\section{Cell staining with Cellstain Hoechst 33258, MelNH-FITC and GlcNH-FITC}

In order to clarify the cell stainability with $\mathrm{H} 33258$, MelNH-FITC and GlcNH-FITC fluorescent dyes, the

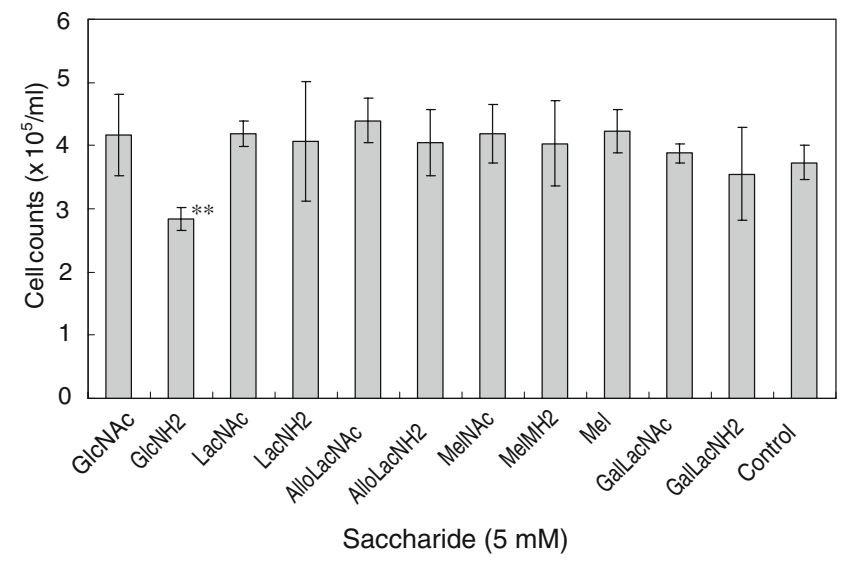

Fig. 2 Effects of saccharides on the proliferation of human normal HUC-F2 cells. Data are shown as the mean \pm SD $(n=3$ for all saccharide samples). ${ }^{* *} p<0.01$ compared with the control

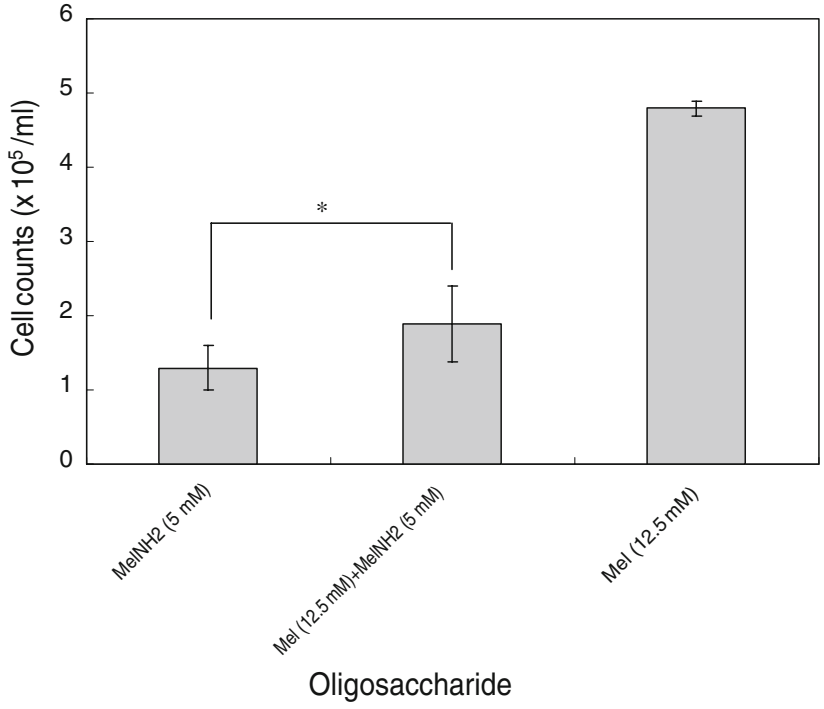

Fig. 3 Inhibition against $\mathrm{MelNH}_{2}$ suppressive effect on $\mathrm{K} 562$ cell by Mel The cell was cultured with $12.5 \mathrm{mM} \mathrm{Mel} \mathrm{for} 1 \sim 2 \mathrm{~h}$ prior to addition of $5 \mathrm{mM} \mathrm{MelNH}$, and after $72 \mathrm{~h}$ incubation the remaining cell was counted. Data are shown as the mean $\pm \mathrm{SD}$. $(n=3$ for all saccharide samples). ${ }^{*} p<0.05$ compared the $\mathrm{MelNH}_{2}$ with the $\mathrm{Mel} \pm \mathrm{MelNH}_{2}$

K562 cells were observed under the fluorescent microscope after dyeing. As shown in Fig. 4, $1 a$, when the cells were cultured for $24 \mathrm{~h}$ without any saccharide and stained with H33258, most cells were of a good shape and dark blue. Moreover, no cells showed any nuclear aggregation. With MelNH-FITC, however, most of the cells did not show staining and they were black under the fluorescent microscope (Fig. 4, 1c). Incubation of cells with $5 \mathrm{mM}$ $\mathrm{GlcNH}_{2}$ or $\mathrm{MelNH}_{2}$ for $24 \mathrm{~h}$ showed that a few cells were bright with $\mathrm{H} 33258$ staining. But most cells did not show staining with MelNH-FITC (data not shown): thus the situation was almost the same as the control incubation for $24 \mathrm{~h}$. The incubation for $72 \mathrm{~h}$ with no specially added saccharide gave the result that several cells were bright (H33258) and their nuclear chromatin was detected to be aggregated (Fig. 4, 2a), but almost all were not stained with MelNH-FITC (Fig. 4, 2c). Moreover, the incubation of cells with $5 \mathrm{mM} \mathrm{GlcNH} \mathrm{H}_{2}$ for $72 \mathrm{~h}$ gave the result that about half of them were brightly stained with $\mathrm{H} 33258$ and their chromatin was aggregated, but only several cells were greenish in the case of MelNHFITC staining, as shown in Fig. 4, $3 a$ and $3 c$. On the other hand, when cells were cultured with $5 \mathrm{mM} \mathrm{MelNH}{ }_{2}$ for $72 \mathrm{~h}$, all cells showed aggregated nuclear chromatin (Fig. 4, 4a), and they were also stained with MelNH-FITC (Fig. 4, 4c).

When cell staining with GlcNH-FITC was carried out after incubation with $5 \mathrm{mM} \mathrm{GlcNH}_{2}$ and $\mathrm{MelNH}_{2}$ for $72 \mathrm{~h}$, 


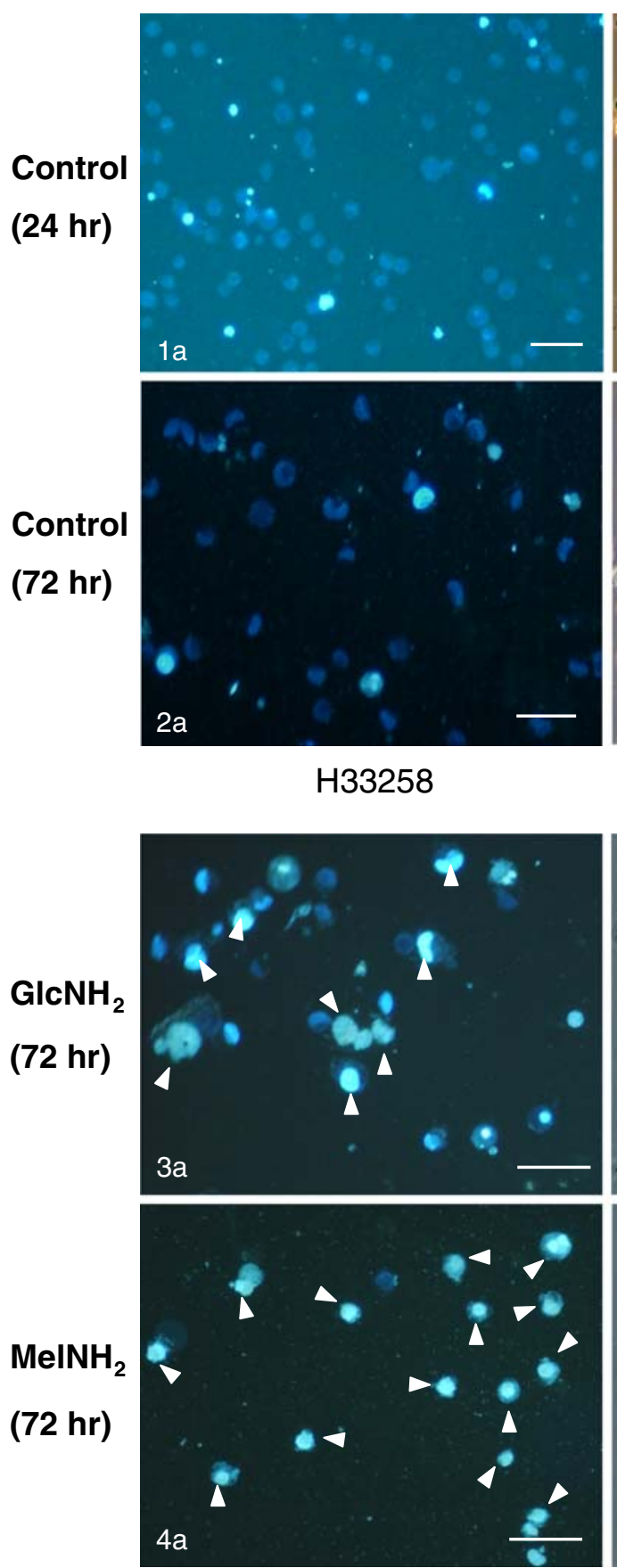

H33258

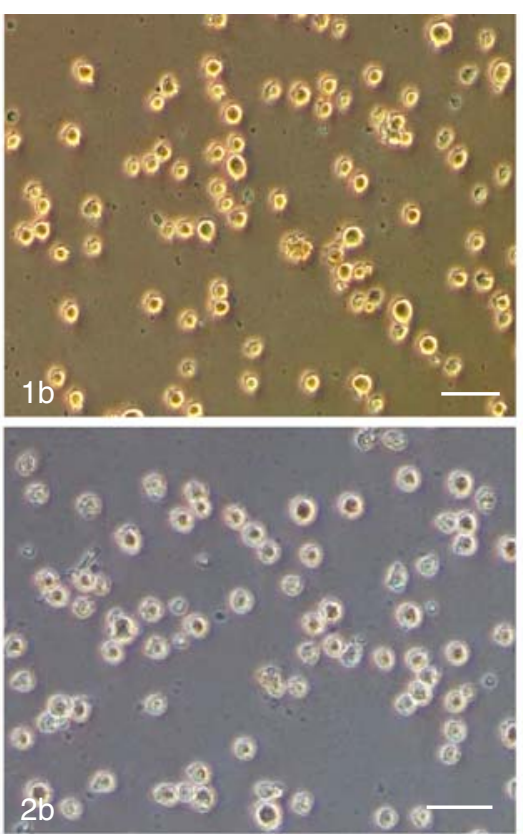

Optical
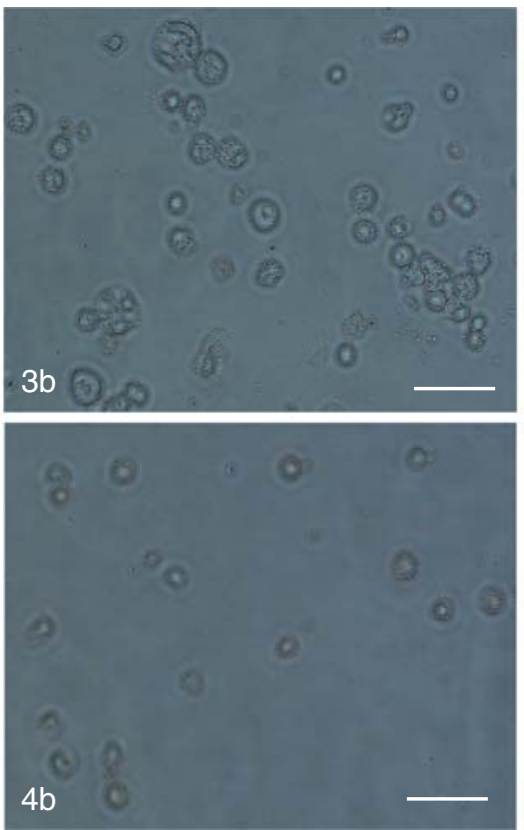

Optical

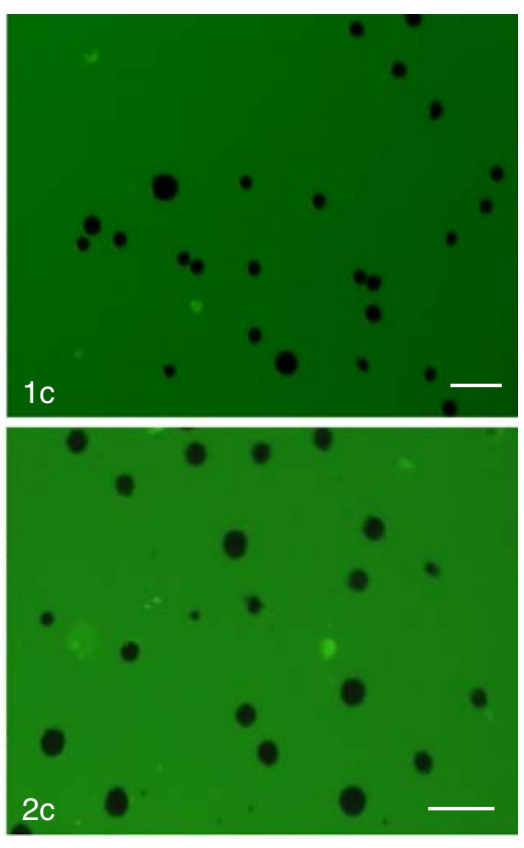

MeINH-FITC
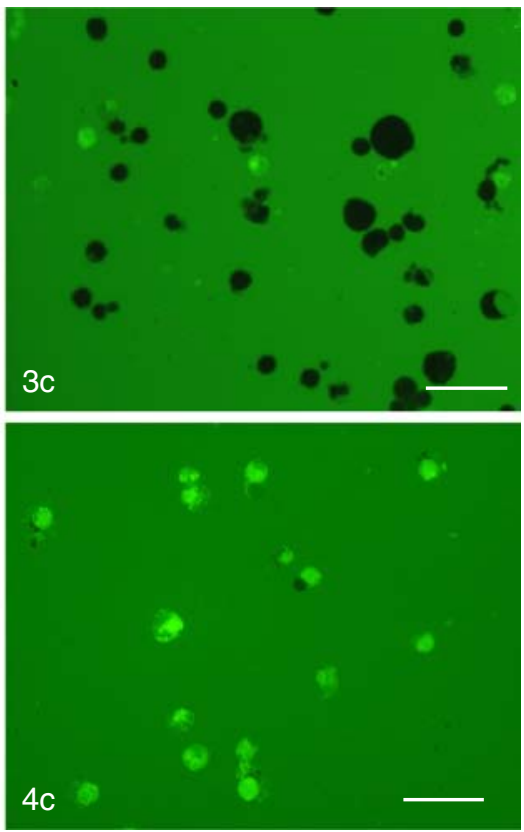

MeINH-FITC
Fig. 4 K562 cell staining by Hoechst 33258 and MelNH-FITC Each cell sample was stained with Hoechst 33258 and MelNH-FITC after 24 and $72 \mathrm{~h}$ cell incubation with or without saccharides $\left(\mathrm{GlcNH}_{2}\right.$ and

among the cells incubated with $\mathrm{MelNH}_{2}$ more than half were not stained (Fig. 5, 2c).

Furthermore, when any oligosaccharide $(5 \mathrm{mM})$ having a GlcNAc residue was added to the cell culture, chromatin aggregation was observed to be only of the same grade as that of the control (data not shown).
$\mathrm{MelNH}_{2}$ ), and observed under the fluorescent microscopy ( $a$ and $c$ ). Each cell sample (stained with H33258) was also observed optically (b) at $\times 200$ magnification. Bar, $100 \mu \mathrm{m}$

SDS-PAGE of the fraction eluted from the melibiose-agarose column

Each fraction which was eluted from the Mel-conjugated column was loaded on SDS-PAGE under non-reducing condition and the slab gel was stained by silver (data not 


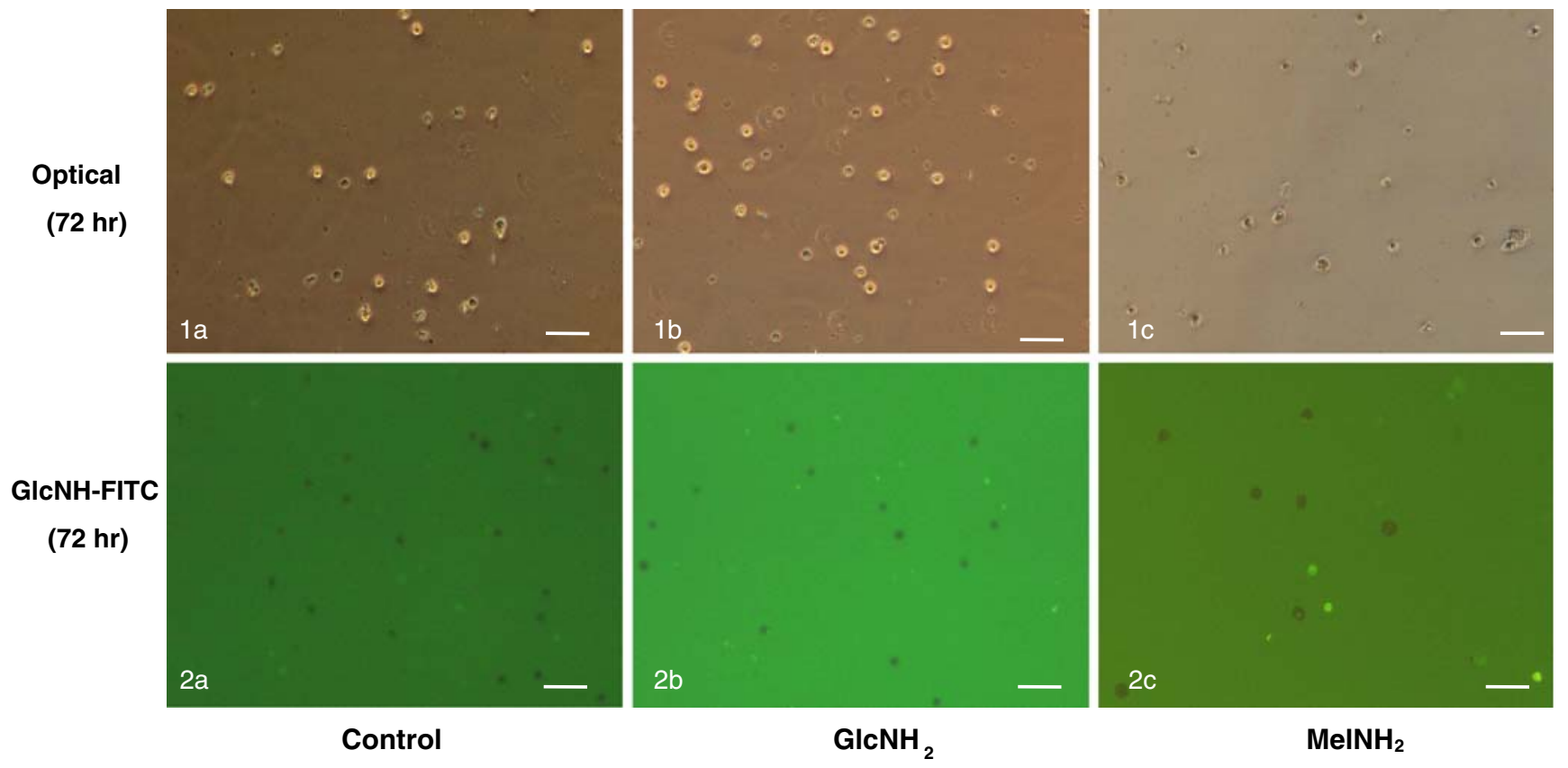

Fig. 5 Stainability of K562 cells with GlcNH-FITC after adding of $\mathrm{GlcNH}_{2}$ and $\mathrm{MelNH}_{2}$ After $72 \mathrm{~h}$ incubation of cells with $\mathrm{GlcNH}_{2}$ and $\mathrm{MelNH}_{2}$, cell samples were stained by GlcNH-FITC and were

shown). The fractions, Nos. 6 9, were collected, concentrated to about $0.3 \mathrm{ml}$ and applied again on SDS-PAGE. As shown in Fig. 6, one main $(76.0 \mathrm{kDa})$ and one minor $(48.0 \mathrm{kDa})$ band were detected under non-reducing conditions, and one major (30.8 $\mathrm{kDa})$ band was detected under reducing conditions. Thus the Mel binding protein(s) was effectively purified by one step affinity chromatography.

Identification of the $\mathrm{MelNH}_{2}$ binding protein by LC-MS/MS analysis and immunological method

Sequences of several peptides which were obtained from the $30.8 \mathrm{kDa}$ protein band on the SDS-PAGE were

Fig. 6 SDS-PAGE of the Melbinding protein obtained from the affinity chromatography Lane NR: Sample was not treated by reducing reagent. Lane $R$ : The same sample was treated by two ME reducing reagent. Standard proteins were myosin $(188 \mathrm{kDa})$, phos phorylase B (97 kDa), glutamic dehydrogenase $(51 \mathrm{kDa})$, carbonic anhydrase $(33 \mathrm{kDa})$, myoglobin blue $(21 \mathrm{kDa})$ and myoglobin red $(19 \mathrm{kDa})$

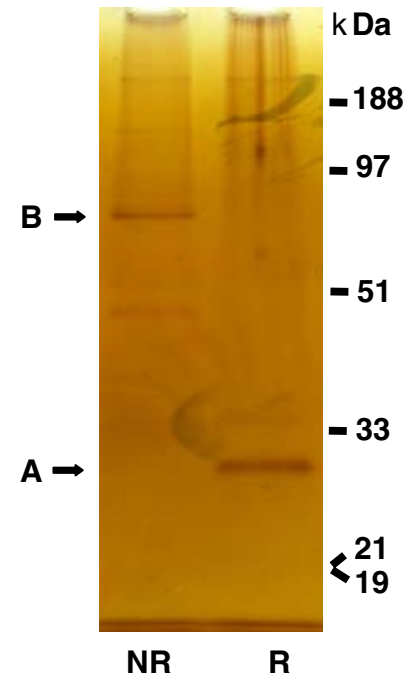

observed optically $(1 a \sim 1 c)$ and under fluorescent $(2 a \sim 2 c)$ microscopy at $\times 200$ magnification. Bar, $100 \mu \mathrm{m}$

analyzed and determined by trypsin digestion and LC-MS/ MS analysis, and each peptide consisted of 12 19 amino acids (Fig. 7). From the result of sequences of peptides hnRNP A1 (34.3 kDa) isoform protein $(30.8 \mathrm{kDa})$ was identified as a candidate with sequence coverage of $25 \%$ as shown in Fig. 7.

As shown in Fig. 8, when the elutants from the MelNHagarose column were immunostained by anti-hnRNP A1 monoclonal and HRP-anti-mouse $\operatorname{IgG}(\gamma)$ antibodies on PVDF membrane, the hnRNP A1 was only detected in the

1 MSKSESPKEP EQLRKLFIGG LSFETTDESL RSHFEQWGTL 41280 TDCVNMRPN TKRSRGFGEV TYATVEEVDA AMNARPHKVD Bl

120

GRVVEPKRAV SREDSQRPGA HLTVKKIFVG GIKEDTEEHH

$121 \quad 160$

LRDYFEQFGK IEVIEIMTDR GSGKKKGFAF VTFDDHDSVD

1612200

ßIVIQKYHTV NGHNCEVRKA LSKOEMASAS SSORGRSGSG 201

240

NFGGGRGGGF GGNDNFGRGG NFSGRGGFGG SRGGGGYGGS

241

280

GDGYNGFGND GSNFGGGGSY NDFGNYNNOS SNFGPMKGGN

261

320

FGGRSSGPYG GGGQYFAKPR NQGGYGGSSS SSSYGSGRRE

Fig. 7 Human hnRNP A1 amino acid sequence The amino acid sequence of human hnRNP A1 was determined by Buvoli et al. [28], and was about $34.3 \mathrm{kDa}$. Amino acids sequences circled with squares are identified as agreeing with our analysis data 


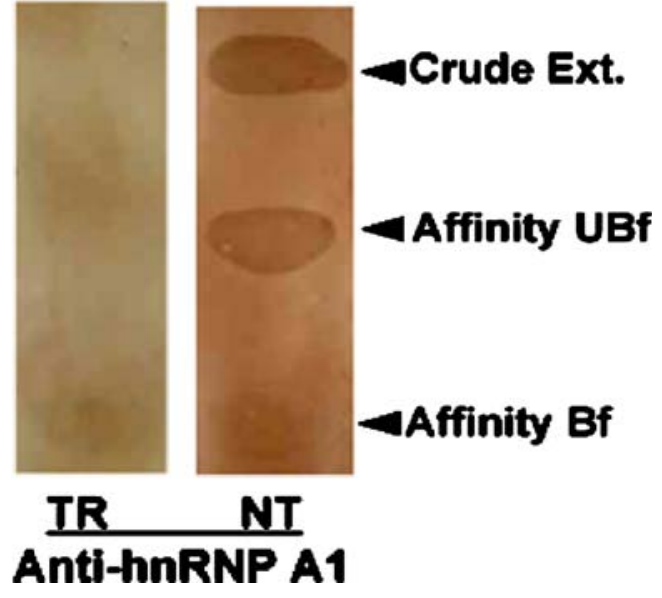

Fig. 8 Detection of hnRNP A1 protein on the PVDF membrane by immunological method Crude Ext.; K562 cell extract fraction, UBf; unbound fraction to the MelNH-agarose column, $B f$; bound fraction to the same column, $T R$; Each sample was treated with $0.3 \% \mathrm{H}_{2} \mathrm{O}_{2}$ methanol at room temperature for $30 \mathrm{~min}$ in order to inactivate endogenous peroxidase activities, NT; not treated with $\mathrm{H}_{2} \mathrm{O}_{2}$-methanol

fraction eluted with $0.1 \mathrm{M} \mathrm{MelNH}_{2}$ after sample blotting and treating the membrane with $0.3 \% \quad \mathrm{H}_{2} \mathrm{O}_{2}$-methanol (Fig. 8). However, the dark brown spots were also detected on all untreated spots.

\section{Discussion}

We showed that novel synthesized oligosaccharides, especially $\mathrm{MelNH}_{2}\left(\mathrm{Gal} \alpha 1-6 \mathrm{GlcNH}_{2}\right)$, had the strongest inhibitory activity on the cancer cell proliferation of human leukemia cells (K562), but not on normal cells (HUC-F2; Figs. 1 and 2). Moreover, $\mathrm{GlcNH}_{2}$ monosaccharide was also an inhibitor of the cancer and normal cells. Quastel and Cantero have reported that daily injection of $\mathrm{GlcNH}_{2}$, intraperitoneally, into mice with tumors showed suppressive effect on the growth of the tumors, and they expected that administration of $\mathrm{GlcNH}_{2}$ might divert ATP activity to affect the rates of the metabolic paths involved in tumor proliferation [11]. They also showed that the radioactive intermediates found following the administration of glucosamine- ${ }^{14} \mathrm{C}$ were GlcNAc-6P, GlcNAc-1P, $\mathrm{GlcNH}_{2}-$ 6P, UDP-GlcNAc, UDP-GalNAc and sialic acid, and they expected that glucosamine derivatives had a cytotoxic effect on the tumors, which should be most sensitive to glucosamine. Ichikawa et al. reported that incubation of mastocytoma P-815 cells with $5 \mathrm{mM}$ glucosamine resulted in a marked inhibition of the cell growth [14]. They further reported that the cellular uptake and oxidation of glucose and the cellular level of ATP were significantly reduced by addition of glucosamine, and that a diminishing of uridine nucleotides and an accumulation of UDP-GlcNAc were observed. In our study, addition of $\mathrm{GlcNH}_{2}$ to the $\mathrm{K} 562$ cell culture decreased the cell numbers of the K562. Thus we suppose that $\mathrm{GlcNH}_{2}$ should also divert ATP activity, and that its derivatives should damage cancer cells. The precise mechanism of the reduction of the cancer cells, however, remains unclear.

On the other hand, the degree of suppressive activity of $\mathrm{MelNH}_{2}$ against the $\mathrm{K} 562$ cell proliferation was higher than that of $\mathrm{GlcNH}_{2}$, although the same concentrations of these saccharides (5 $\mathrm{mM}$ each) were used for this examination. Furthermore, the $\mathrm{MelNH}_{2}$ addition to the K562 cell culture decreased the cell numbers to a greater degree than those of other oligosaccharides which had $\mathrm{GlcNH}_{2}$ residue $\left(\mathrm{LacNH}{ }_{2}, \mathrm{AlloLacNH} \mathrm{H}_{2}\right.$ and GalLacNH$\left.{ }_{2}\right)$, as shown in Fig. 1A. These results suggest that it is unreasonable to think that $\mathrm{MelNH}_{2}$ might be hydrolyzed to two monosaccharides $\left(\mathrm{Gal}\right.$ and $\left.\mathrm{GlcNH}_{2}\right)$ and that the $\mathrm{GlcNH}_{2}$ residue functions as an inhibitor against cancer cell proliferation. Supposing this assumption is correct, the influence of $\mathrm{GlcNH}_{2}$ on the $\mathrm{K} 562$ cells must be greater than that of $\mathrm{MelNH}_{2}$. Thus we expect that the administration effects of $\mathrm{MelNH}_{2}$ and $\mathrm{GlcNH}_{2}$ on the $\mathrm{K} 562$ cells indicate the differences between their metabolic pathways in cancer cells.

Furthermore, chito-disaccharide might have a slight inhibitory effect on K562 cells, but other chito-oligosaccharides (tri-, tetra- and penta-) showed no suppressive affect on the cell proliferation, indicating that chito-oligosaccharides were neither taken up into the cell nor metabolized (Fig. 1B). It seems quite likely that chito-disaccharide or other chitooligosaccharides could be neither hydrolyzed in the cell culture systems nor absorbed on the cell surface.

The results of the preincubation examination of K562 cells with Mel prior to the incubation with $\mathrm{MelNH}_{2}$ showed a moderate decrease in the anti-proliferation activity of $\mathrm{MelNH}_{2}$. This suggests that the same receptor(s) against $\mathrm{MelNH}_{2}$ and Mel is present on the cell (Fig. 3), and that the former has a higher affinity than the latter.

After incubation of the $\mathrm{K} 562$ cell with $\mathrm{MelNH}_{2}$ or $\mathrm{GlcNH}_{2}$, the cell was stained with H33258, MelNH-FITC and GlcNH-FITC, as shown in Figs. 4, $1 a \sim 4 c$ and 5. The degree of stainability of the K562 cell changed with progress of time and a drastic change seemed to occur about $48 \mathrm{~h}$ incubation after. This suggests that the influence of $\mathrm{MelNH}_{2}$ or $\mathrm{GlcNH}_{2}$ upon the K562 leukemia cells increased slowly. After incubation for $72 \mathrm{~h}$ with $\mathrm{MelNH}_{2}$, every cell was stained with these two fluorescence dyes (H33258 and MelNH-FITC) and their nuclear chromatin aggregations were identified as light blue ones (Fig. 4, $4 a$ and $4 c$ ). However, although $\mathrm{GlcNH}_{2}$ showed a suppressive effect against the K562 cell proliferation, only half of the cells were stained with $\mathrm{H} 33258$ after $72 \mathrm{~h}$ incubation and the cells were not sufficiently stained by MelNH-FITC 
(Fig. 4, $3 a$ and 3c). Furthermore, as described in these figures, the brightly stained cells which showed nuclear chromatin aggregation with $\mathrm{H} 33258$ were determined to have shown cell death induced by these saccharides and most cells died after $\mathrm{MelNH}_{2}$ addition (Fig. 4, $4 a$ and $4 c$ ). On the other hand, staining of the cells with GlcNH-FITC showed a difference from that with MelNH-FITC (Figs. 4, 4 and 5), suggesting that there might be some uptake pathways of these saccharides. Thus these results suggest that the cell death pathway of $\mathrm{K} 562$ cells induced by $\mathrm{MelNH}_{2}$ differs from that induced by $\mathrm{GlcNH}_{2}$ and that at least some cell death pathways induced by saccharides might be present. We hope that the $\mathrm{MelNH}_{2}$ and $\mathrm{Mel}$ specific receptor protein(s) exists in/on the K562 cell membrane and that the cell takes up and transport these saccharides by this molecule(s).

We determined by LC-MS/MS analysis and immunological method that the $\mathrm{Mel} / \mathrm{MelNH}_{2}$ binding protein is the hnRNP A1 isoform, and that this protein had an apparent molecular mass of $30.8 \mathrm{kDa}$ on SDS-PAGE (Figs. 6, 7 and 8). Human hnRNP A1 is a single-stranded nucleic acidbinding protein, which has many functions in various aspects of mRNA maturation and in telomere length regulation $[20,21]$. On the other hand, Murzin et al. have observed a novel folding motif in four different proteins, which bind oligonucleotides or oligosaccharides: in nuclease, anticodon binding domain of asp-tRNA synthetase and B-subunits of heat-labile enterotoxin and verotoxin-1 (in some enzymes and toxins) [22]. They called the OB-fold in which a five-stranded $\beta$-sheet was coiled to form a closed $\beta$-barrel. Moreover, the hnRNP protein is predicted to have a very closely related motif and to bind to oligosaccharide (e.g. lactose) as well as oligonucleotide [22, 23]. It was shown that the hnRNP was shuttling between the nucleus and the cytoplasm [24]. Celis et al. and LeStourgeon et al. reported that there was a marked difference in the concentration of hnRNP A1 between resting or dividing cells and rapidly dividing cells $[25,26]$, and $\mathrm{Xu}$ et al. demonstrated that levels of hnRNP A1 were elevated in some cancers [27]. We observed that $\mathrm{MelNH}_{2}$ and $\mathrm{GlcNH}_{2}$ did not significantly influence the K562 cells, which had been cultivating for about 6 months and that the division speed decreased (data not shown), and that the human normal cell (HUC-F2) was controlled by only $\mathrm{GlcNH}_{2}$ but not $\mathrm{MelNH}_{2}$. We have carried out an experiment on the influence of some saccharides on the human B cell derived leukemia cell line (BALL cells), and found that the BALL cells was also controlled with $\mathrm{MelNH}_{2}, \mathrm{GlcNH}_{2}$ and alloLacNH $\mathrm{N}_{2}$ (data not shown). We think that novel oligosaccharides containing amino-sugar (e.g. glucosamine) show a certain effect on the leukemia cell lines in vitro. Thus we suppose that a molelule having specific affinity against $\mathrm{MelNH}_{2}$ appears in the $\mathrm{K} 562$ cells and that it is elevated on/ in the cancer cell membrane, and that $\mathrm{MelNH}_{2}$ taken into cells disturbs the abilities of the hnRNP to mature mRNA regulating telomere length or to perform other significant function(s) for the cancer cell proliferation and survival. Thus, although it is not clear how $\mathrm{MelNH}_{2}$ is taken into the $\mathrm{K} 562$ cells, we hope that the $\mathrm{MelNH}_{2}$ binding protein (hnRNP A1 isoform) plays important roles in transporting $\mathrm{MelNH}_{2}$ into the cell nucleus via the cytoplasm. However, the molecule which was expected to be the receptor on/in the cell membrane was not detected in this study. This will be a subject of our research in the near future.

Acknowledgements This research was supported by grants from the Institute of Sports, Health and Medical Science, Juntendo University. We thank Drs. D. Ohmori, K. Ikeda, B. Allen R. Mineki and H. Taka for their excellent technology and suggestions.

Open Access This article is distributed under the terms of the Creative Commons Attribution Noncommercial License which permits any noncommercial use, distribution, and reproduction in any medium, provided the original author(s) and source are credited.

\section{References}

1. Stockwell, R.A., Scott, J.E.: Distribution of acid glycosaminoglycans in human articular cartilage. Nature 215, 1376-1378 (1967). doi:10.1038/2151376a0

2. Partrige, S.M., Davis, H.F., Adair, G.S.: The chemistry of connective tissues. 6. The constitution of the chondroitin sulphate-protein complex in cartilage. Biochem. J. 79, 15-26 (1961)

3. Baxter, B., Muir, H.: The nature of the protein moieties of cartilage proteoglycans of pig and ox. Biochem. J. 149, 657-668 (1975)

4. Malemud, C.J., Goldberg, V.M., Moskowitz, R.W., Getzy, L.L., Papay, R.S., Norby, D.P.: Biosynthesis of proteoglycan in vitro by cartilage from human osteochondrophytic spurs. Biochem. J. 206, 329-341 (1982)

5. Meininger, C.J., Kelly, K.A., Li, H., Haynes, T.E., Wu, G.: Glucosamine inhibits inducible nitric oxide synthesis. Biochem. Biophys. Res. Commun. 279, 234-239 (2000). doi:10.1006/ bbrc.2000.3912

6. Zerkak, D., Dougados, M.: The use of glucosamine therapy in osteoarthritis. Curr. Rheumatol. Rep. 6, 41-45 (2004). doi:10.1007/ s11926-004-0082-4

7. Fenton, J.I., Chlebek-Brown, K.A., Peters, T.L., Caron, J.P., Orth, M.W.: Glucosamine $\mathrm{HCl}$ reduces equine articular cartilage degradation in explant culture. Osteoarthritis Cartilage 8, 258265 (2000). doi:10.1053/joca.1999.0299

8. Barclay, T.S., Tsourounis, C., McCart, G.M.: Glucosamine. Ann. Pharmacother. 32, 574-579 (1998). doi:10.1345/aph.17235

9. Houpt, J., McMillan, R., Wein, C., Paget-Dellio, S.D.: Effect on glucosamine hydrochloride in the treatment of pain of osteoarthritis of the knee. J. Rheumatol. 26, 2423-2430 (1999)

10. McCarty, M.F.: Glucosamine for wound healing. Med. Hypotheses 47, 273-275 (1996). doi:10.1016/S0306-9877(96)90066-3

11. Quastel, J.H., Cantero, A.: Inhibition of tumor growth by Dglucosamine. Nature 171, 252-254 (1953). doi:10.1038/171252a0

12. Molnar, Z., Bekesi, J.G.: Effects of D-glucosamine, Dmannosamine, and 2-deoxy-D-glucose on the ultrastructure of ascites tumor cells in vitro. Cancer Res. 32, 380-389 (1972a) 
13. Molnar, Z., Bekesi, J.G.: Cytotoxic effects of D-glucosamine on the ultrastructures of normal and neoplastic tissues in vivo. Cancer Res. 32, 756-765 (1972b)

14. Ichikawa, A., Takagi, M., Tomita, K.: Effect of D-glucosamine on growth and several functions of cultured mastocytoma P-815 cells. J. Pharmacobiodyn. 3, 577-588 (1980)

15. Sharma, A., Ahmed, H., Allen, H.J.: Isolation of a melibiosebinding protein from human spleen. Glycoconj. J. 12, 17-21 (1995). doi:10.1007/BF00731864

16. Appukuttan, P.S.: Terminal a-linked galactose rather than Nacetyllactosamine is ligand for bovine heart galectin-1 in N-linked oligosaccharides of glycoproteins. J. Mol. Recognit. 15, 180-187 (2002). doi:10.1002/jmr.573

17. Perillo, N.L., Pace, K.E., Seilhamer, J.J., Baum, L.G.: Apoptosis of T cells mediated by galectin-1. Nature 378, 736-739 (1995). doi: $10.1038 / 378736 \mathrm{a} 0$

18. McReynolds, K.D., Bhat, A., Conboy, J.C., Saavedra, S.S., Gervay-Hague, J.: Non-natural glycosphingolipids and structurally simpler analogues bind HIV-1 recombinant Gp120. Bioorg. Med. Chem. 10, 625-637 (2002). doi:10.1016/S0968-0896(01) 00325-X

19. Mineki, R., Taka, H., Fujimura, T., Kikkawa, M., Shindo, N., Murayama, K.: In situ alkylation with acrylamide for identification of cysteinyl residues in proteins during one- and two-dimensional sodium dodecyl sulphate-polyacrylamide gel electrophoresis. Proteomics 2, 1672-1681 (2002). doi:10.1002/1615-9861(200212) 2:12<1672::AID-PROT1672>3.0.CO;2-\#

20. Carpenter, B., Mackay, C., Alnabulsi, A., MacKay, M., Telfer, C., Melvin, W.T., et al.: The roles of heterogeneous nuclear ribonucleoproteins in tumour development and progression. Biochim. Biophys. Acta. 1765, 85-100 (2006)
21. Zhang, Q.S., Manche, L., Xu, R.M., Krainer, A.R.: hnRNP A1 associates with telomere ends and stimulates telomerase activity. RNA 12, 1116-1128 (2006). doi:10.1261/rna.58806

22. Murzin, A.G.: OB(oligonucleotide/oligosaccharide binding)-fold: common structural and functional solution for non-homologous sequences. EMBO J. 12, 861-867 (1993)

23. Ding, J., Hayashi, K.M., Zhang, Y., Manche, L., Krainer, A.R., Rui-Ming, X.: Crystal structure of the two-RRM domain of hnRNP A1 (UP1) complexed with single-stranded telomeric DNA. Genes Dev. 13, 1102-1115 (1999). doi:10.1101/gad.13.9.1102

24. Pinol-Rome, S., Dreyfuss, G.: Shuttling of pre-mRNA binding proteins between nucleus and cytoplasm. Nature 355, 730-732 (1992). doi:10.1038/355730a0

25. Celis, J.E., Bravo, R., Arenstorf, H.P., Lestourgeon, W.M.: Identification of proliferation-sensitive human proteins amongst components of the $40 \mathrm{~S}$ hnRNP particles. Identity of hnRNP core proteins in the HeLa protein catalogue. FEBS Lett. 194, 101-109 (1986). doi:10.1016/0014-5793(86)80059-X

26. Lestourgeon, W.M.B.A., Christensen, M.E., Walker, B.W., Poupore, S.M., Daniels, L.P.: The packaging proteins of core hnRNP particles and the maintenance of proliferative cell stages. Cold Spring Harb. Symp. Quant. Biol. 42, 885-898 (1978)

27. Xu, X., Joh, H.D., Pin, S., Schiller, N.I., Prange, C., Burger, P.C., et al.: Expression of multiple larger-sized transcripts for several genes in oligodendrogliomas: potential markers for glioma subtype. Cancer Lett. 171, 67-77 (2001). doi:10.1016/S03043835(01)00573-0

28. Buvoli, M., Biamonti, G., Tsoulfas, P., Bassi, M.T., Ghetti, A., Riva, S., et al.: cDNA cloning of human hnRNP protein A1 reveals the existence of multiple mRNA isoforms. Nucleic Acids Res. 16, 3751-3770 (1988). doi:10.1093/nar/16.9.3751 